\title{
Physicochemical changes of the water of Alvarado Lagoon, Veracruz, Mexico in interrupted periods in middle century
}

\begin{abstract}
Most of the coastal lagoons in the Mexican tropics are environmentally complex, resulting from the evolution of terrestrial river flows and their local marine dynamics; however, anthropogenic management in both environments have accelerated its natural geological evolution, impacting in turn on the physicochemical characteristics and their ranges of variation, as well as trophic levels with a tendency to eutrophication. A typical case of the above is the Alvarado lagoon, Ver, which has been the reason of the present study for the changes in the use of the soil for the diversity of anthropic activities. To determine these impacts three samplings (2015-2016) where basic physicochemical parameters of water were analyzed and compared with previous studies carried out by different authors 50 years ago (approximately), which allowed to estimate that from a natural eutrophication changed to cultural eutrophication, determined mainly by the total concentrations of total nitrogen and phosphorus, as well as the chlorophyll content "a". It was calculated a high export of these nutrients to the marine environment, aided by the great discharge of the Papaloapan river that is located near to the marine intercommunication; in which estimated exports according to the model of LOICZ $77.65 \mathrm{mmol} \mathrm{m}^{-2}$ day for total phosphorus and $479.72 \mathrm{mmol} \mathrm{m}^{-2}$ day for the total nitrogen in the rainy season. Despite the fact that this intercommunication has a residence time of 0.8 days it is possible depurated the water quality of the lagoon, but urban growth and its economic activities (mainly agriculture) increase constantly and do not cease to emit their discharges to the coastal lagoon. Based on the LOICZ balance the lagoon is in a state of heterotrophy.
\end{abstract}

Keywords: Physicochemical trend 50 years, Lagoon Alvarado, Geology, Edaphology, Hydrography
Volume 5 Issue 3 - 2017

\section{Guadalupe de la Lanza Espino}

Salvador Hernández Pulido Institutode Biología, Universidad Nacional Autónoma de México, Mexico

Correspondence: Guadalupe de la Lanza Espino, Salvador Hernández Pulido Institutode Biología, Universidad Nacional Autónoma de México, Mexico, Email gdlle@unam.mx

Received: December 05, 2016 | Published: February 23, 2017

\section{Introduction}

Under pristine environmental conditions, the composition of water in coastal systems depends on the drainage of the hydrological basins that feed them, leading to a water chemistry resulting from the soil structure through which the tributaries of these basins cross, generating gradients between continental water and the marine water (spatial variation). Also, besides the local variation, there is a temporary that in the coasts of Mexico is defined by the times of rains, dry and wind Northes (Fronts) and even by the interannual variation; resulting in a wide oscillation of the chemical constituents of water at different time intervals considered to be normal. However, with the increase in the influence of anthropogenic activities (urban discharges to remote or indigenous rivers, poor management of fisheries, livestock, agriculture, dams and various industries), the range tends to surpass the normal oscillation of physicochemical characteristics (now the so-called water quality), making it deleterious not only for aquatic organisms, but for man as well. This wide variety of factors on coastal systems has been repeatedly reported by many specialists as impacts on these environments, so it would be very broad and redundant to refer them.

In order to determine such influences, fundamental chemical parameters are chosen that allow to establish the physicochemical of the water. Some of them are: temperature, salinity, dissolved oxygen and its saturation, chemical oxygen demand or COD (which measures the organic load) and so-called nutrients (nitrogen salts such as ammonium, nitrites, nitrates, total nitrogen including organic) and orthophosphates with total phosphorus (including organic), with a minimum monitoring per season, but desirable monthly. ${ }^{1}$ The above parameters, plus the determination of the chlorophyll content "a" (as a primary productivity index) allow to define the trophic state of any ecosystem. $^{2}$

To make a diagnosis of a coastal system, it is necessary not only to have the knowledge and experience of the executors, to delineate the temporal space variations with intervals of natural concentrations (taking into account local, regional or national environmental) of coastal lagoons of Mexico, of those impacts whose contents surpass the intervals recognized by the executors, but also to count previous studies and not to be based on norms like NOM ECOL $0011996,{ }^{3}$ which unfortunately is designed for waters that receive urban or industrial discharges, or in the foreign ones that generally come from countries of other latitudes with different geology, edaphology, hydrography, biology and urban and industrial developments, which makes any comparison unacceptable.

It should be noted that due to the accelerated population increase and under climate change that is also occurring in the coastal zone, it is advisable to periodically carry out records of the physicochemical parameters to determine its influence on some lagoon system. When this information is combined with historical data, sedimentary records are of great interest because they offer the possibility of retrospective studies of the factors that have caused and continue to cause environmental changes, which are currently being developed in short time frames and do not provide for any monitoring program. 
The Alvarado lagoon has been studied since the 1960s to the present date (2016), because it is a complex environment important for its geology, hydrography, physicochemistry, biology and for the environmental services that it offers for long time to the man which has taken advantage for the development and population growth in its margins, and whose discharges of black or gray water, even industrial, have been direct to this aquatic system, including the distant ones of other cities as for example those of the Blanco river that passes through Orizaba, Nogales and other towns; in addition to those of the Papaloapan river that receive not only urban but agricultural runoff. This has significantly modified the physicochemistry of the water, without considering the capacity of load and its little or no purification.

Therefore, the present contribution aims to determine the temporal space variation of the physicochemical characteristics of water, primary productivity and estimate the trophic level. For this purpose, representative sites were chosen that included: low or no impact (taking into account previous studies), discharge of the Papaloapan River, Blanco River through the Laguna de Tlalixcoyan, and with or without urban settlements. This was done through three samplings: one in a period known as drought (March), another at the beginning of rains (August) and the third at the time of greatest rainfall. In addition to making a retrospective analysis of 50 years of studies to date in order to determine the change that has undergone this lagoon system.

\section{Description of the study area}

Alvarado Lagoon is located southeast of the State of Veracruz (Alvarado Municipality), on the Southern Coastal Plain of the Gulf of Mexico, locally known as the "Plain de Leeward", between geographic coordinates $18^{\circ} 44^{\prime} 00$ " and $18^{\circ} 52^{\prime}$ ' $15^{\prime} \mathrm{N}$ and $95^{\circ} 44$ ' $00^{\prime}$ ' and $95^{\circ} 57^{\prime}$ ' $00^{\prime} \mathrm{W}^{4}$ (Figure 1). In it flows the Papaloapan river, as well as smaller rivers: the Limón, Blanco, Acula, Camarón, among others. There are other smaller coastal lagoons, among which we can mention Camaronera, Tlalixcoyan, Buen Pais, Popuyeca, Atzizintla, as well as more than 100 lentic bodies intercommunicated within the so-called "Complex or Lagunar System of Alvarado". There are several municipalities in the lower basin of the Papaloapan, including: Alvarado, Tlacotalpan, Acula, Ignacio de la Llave, Tlalixcoyan, Lerdo de Tejada, Ixmatlahuacan, Tierra Blanca, Cosamaloapan, Amatitlán and Carlos A. Carrillo.

The contributions of continental water that the Alvarado Lagoon receives permanently through the rivers, are increased in the rainy season, from "North" (between June and December) and occasionally from extraordinary events such as tropical storms and hurricanes (from the Lanza Espino and Carbajal Pérez, in press). The contribution of sea waters is carried out by the mouth of the Papaloapan river coincident with the marine mouth where a wide estuarine area is formed; also by an artificial channel that communicates to the Camaronera Lagoon with the sea.

Alvarado lagoon and adjacent ecosystems are included in the National Biodiversity Commission or $\mathrm{CONABIO}^{5}$ in several conservation categories, Priority Terrestrial Region (Papaloapan Wetlands), Priority Marine Region (Alvarado Lagoon System), Priority Hydrological Region (Wetlands of Papaloapan, San Vicente and San Juan), Area of importance for the Conservation of AICAS Birds (Wetlands of Alvarado) and is included in the list of Wetlands of International Importance or RAMSAR Sites.

The region where the Laguna de Alvarado is located, presents several environmental problems, mainly due to the change of land use for the construction of roads, filling of flooded areas for agricultural and urban use, mangrove clearing and modification of vegetation by agricultural activities (mainly sugar cane cultivation) in which biocides such as organochlorines and organophosphates are used and even by oil activity as well as waste and discharges from the sugar industry (San Cristóbal, San Gabriel, San Pedro and San Francisco mills) paper industry and other urban discharges (Alvarado, Tlacotalpan, Cosamaloapan, Tuxtepec and the industrial zone of the Córdoba-Orizaba cities). Also, overexploitation of fishery resources, including violation of closures and capture of minimum sizes, and indiscriminate hunting of various species (Botello and Lanza Espino in preparation).

\section{Methodology}

Three samplings were carried out (from 23 to 30 March, 1 to 3 April, from 16 to 17 August 2015 and from 4 to 5 May 2016). For the choice of study stations, the geomorphology of the lagoon, fluvial and tide type influence, as well as the settled settlements in the margins and their possible discharges were taken into account; the stations are shown in Figure 1. In situ parameters (temperature, salinity, dissolved oxygen with their saturation and $\mathrm{pH}$ ) were measured with the HYDROLAB multisensory. Were taken water samples al surface and bottom level for nutrient $\left(\mathrm{NH}_{4}, \mathrm{NO}_{2}, \mathrm{NO}_{3} \mathrm{PO}_{4}\right.$, total nitrogen and phosphorus, $\mathrm{COD}$ and chlorophyll a, which were frozen for chemical analyzes in the laboratory based on the methodology of Strickland and Parsons ${ }^{6}$ and APHA $^{7}$ (Table 1) (Figure 1).The water samples were thawed in the laboratory and the corresponding determinations were made, according to the techniques mentioned in table 1 . To determine the changes Alvarado lagoon system, different bibliographic sources of different years were consulted from the 1960s onwards, to mention a few Villalobos et al. ${ }^{8}$ Flores Coto and Méndez Vargas, ${ }^{4}$ Contreras Espinosa, ${ }^{9}$ Contreras Espinosa et al., ${ }^{2}$ Contreras Espinosa et al., ${ }^{10}$ de la Lanza Espino and Lozano Montes, ${ }^{11}$ Arriaga Cabrera et al., ${ }^{12}$ Contreras Espinosa and Warner. ${ }^{13}$ Morán Silva et al., ${ }^{14}$ Calva Benítez and Torres Alvarado, ${ }^{15}$ Herrera Silveira et al. ${ }^{16}$ Ruiz Fernandez et al. ${ }^{17}$ It should be noted that the oxygen results of the different sources of information were reported in $\mathrm{mg} / \mathrm{L}$ and others in $\mathrm{ml} / \mathrm{L}$ that were homogenized based on $\mathrm{mg} / \mathrm{L}=1.43 \mathrm{x} \mathrm{mL} / \mathrm{L} .{ }^{18}$ Due to the inequality in the number of parameters in the 50 years analyzed by the different authors, it was decided to make a detailed written analysis and not to refer it in tables since frequent empty voids would appear.

\section{Results and discussion}

During the three samplings carried out in the present study, significant spatial and temporal physico-chemical changes were observed in the Alvarado lagoon (Table 2). It was determined that the warmest temperature was in August with a difference of $2{ }^{\circ} \mathrm{C}$ compared to March; being barely colder in the bottom level both months except in the marine intercommunication. In 1966 Villalobos et al. ${ }^{8}$ recorded the coldest month to March $\left(21^{\circ} \mathrm{C}\right)$ and the hottest August $31{ }^{\circ} \mathrm{C}$ difference more marked than recorded 50 years later (2015). In May 2016 (beginning of the rainy season) the temperature was homogeneous with $27^{\circ} \mathrm{C}$. In $1986-87$ de la Lanza-Espino \& Lozano Montes ${ }^{11}$ determined as the warmest months May and September with $295^{\circ} \mathrm{C}$, Arriaga Cabrera et al. ${ }^{12}$ recorded an average temperature of $24^{\circ} \mathrm{C}(\min 9.5 \max .48)$ and RuízFernández et al. $(2014)^{17}$ report an annual average of $22^{\circ} \mathrm{C}$ with a temperature of over $18^{\circ} \mathrm{C}$ in the coldest month; differences that may be due to the time the registration was made, although there is the possibility of inter and intra-annual variation. To this physical variation must be added the tropical latitudinal location in which Mexico, is the reason of the wide interval between epochs, for which it cannot be said that there has been a thermal increase in the 50 years and even more subject to the influence of tropical cyclones (From de la Lanza Espino et al., accepted). 
Table I Parameters and their physicochemical techniques used in the physicochemical study of the Alvarado Laguna, Veracruz

\begin{tabular}{llll}
\hline $\begin{array}{l}\text { Parameter } \\
\text { temperature }\end{array}$ & Technique & $\begin{array}{l}\text { Basis } \\
\text { hidrolab }\end{array}$ & Instrumental \\
\hline Salinity & Conductivity Relationship & Measurement of Conductivity & Hidrolab YSI 556 MPS \\
Dissolved Oxygen & Electrometric & Silver Sensor with Teflon Membrane & Hidrolab and Si556 MPS \\
$\mathrm{pH}$ & Electrometric & Sensor Combine Pt-Cd & Hidrolab YSI 556 MPS \\
Nutrients NO2NO3PO4NH4 & Spectrophotometric & Color Complex & Spectrophotometer \\
Nitrogen and Total Phosphorus & Digestion & Digestion: K2S2O8 at $150^{\circ}$ and $105^{\circ}$ C, respectively & Spectrophotometer \\
COD & Titulometry & Oxide Reduction & Titulometry \\
Chlorophyla & Spectrophotometric & Extraction with Acetone & Spectrophotometer \\
\hline
\end{tabular}

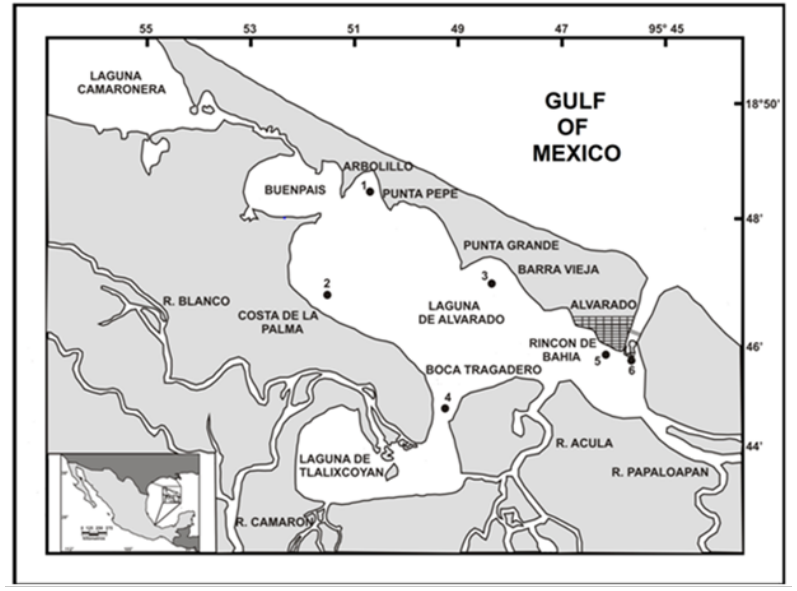

Figure I Alvarado lagoon location and water sample sites for physiochemica studies.

The salinity recorded in 2015 showed marked spatial and temporal differences in March it oscillated from oligohaline (2.77 ups) in the Tlalixcoyan lagoon fed by the Blanco river, to the mesohaline in Rincon Bahia station (19 ups) and the major haline contents were at bottom level; in August salinity decreased ostensibly to limnic levels (less than 0.3 ups) to oligohaline ( 3 ups on average) except for the bottom level in the mouth (marine intercommunication) due to salt wedge where concentrations of 32 ups were quantified in May 2016 the salinity varied between the mesohaline interval ( 4.9 to 6.6 ups), but in the mouth an oligohaline condition ( 2 ups) was observed in the surface and polyhaline-marine in the bottom level (31 ups). Villalobos et al. ${ }^{8}$ recorded mesohaline to marine levels in April and oligohalins in September. From de la Lanza Espino \& Lozano ${ }^{11}$ in March 1986-87 they determined saline levels between 4 and 18 ups corresponding to Tlalixcoyan and Camaronera, respectively, with an increase in May including Tlalixcoyan and a marked decrease in September of the limnetic 0.0 ups to oligohalin including Camaronera lagoon (4 ups); also Arriaga Cabrera et al. ${ }^{12}$ determined the Alvarado Lagoon as a system that has oscillated between oligohaline or limnetic to mesohaline (0 to 24 ups). On the other hand, Contreras Espinosa \& Warner ${ }^{13}$ indicated intervals between 7.8 to 33.5 ups during an annual period between 1996-1997. Calva Benitez \& Torres Alvarado ${ }^{15}$ estimated an average of 8.6 in the dry season and 2.2 to 5.2 ups in rain-north; although it is acceptable to refer to salinity as an average, it does not give importance to the spatial variation, necessary for the compression of certain biological processes of many species and the biogeochemical conditions associated with the nutrients. Salinity is considered as a conservative (non-reactive biologically and chemically), its concentration does not depend only on dry and rainy seasons of normal or extreme conditions (tropical cyclones), but also on river runoff, which in the case of the Alvarado lagoon discharge just over 11 rivers some of them of high basins, given its wide variation. It is estimated that its haline range has remained similar in more than 50 years.

In the present study, the variation of the dissolved oxygen content ranged in March between levels near hypoxia (42\% saturation), especially in the bottom north of the lagoon, up to $7.85 \mathrm{mg} / \mathrm{L}(92 \%$ saturation). In August, a maximum saturation percentage of $67 \%$ was recorded, although in the estuarine area (La Boca area), where it reached $96 \%$, a close condition in May, where it was determined from 83 to $>100 \%$ saturations. This gas is considered as non-conservative with daily marked oscillations and by normal or extreme climatic epoch like tropical cyclones, cold fronts and wind Northes; as well as geomorphological characteristics, and the phyto planktonic activity; condition that it is not acceptable to refer to averages because of the greater variation. Compared with that reported 50 years ago by Villalobos et al., ${ }^{8}$ it also determined a wide range of variation between hypoxic (less than $3.5 \mathrm{mg} / \mathrm{L}$ or less than $45 \%$ saturation) at the bottom level and supersaturation at surface level $(14 \mathrm{mg} / \mathrm{L}>100 \%$ saturation $)$. Che Barragan ${ }^{19}$ in 1972-73 compared to the communication with the Tlalixcoyan lagoon recorded contents of this gas of $3.8 \mathrm{mg} / \mathrm{L}$ close to $45 \%$ saturation. De la Lanza Espino \& Lozano Montes (1999) ${ }^{11}$ register high contents of $10.3 \mathrm{mg} / \mathrm{L}$ (100\% saturation) to $18 \mathrm{mg} / \mathrm{g}(150 \%$ of sat.) but lower in September $(1.5 \mathrm{mg} / \mathrm{L})$ were observed in $1987-86$ or less than $40 \%$ sat) to more of $14 \mathrm{mg} / \mathrm{L}(116 \%$ sat $)$. Contreras Espinosa and Warner ${ }^{13}$ reported between 1996-1997 contents of 3 to $11 \mathrm{mg} / \mathrm{L}$ with an average saturation of $105 \%$; Morán-Silva et al. ${ }^{14}$ determined in 2000-01 broad contents of this gas that ranged from $18.3 \mathrm{mg} / \mathrm{L}$ to 5.9 $\mathrm{mg} / \mathrm{L}$ depending on the hour and locality. The wide intervals were the result of this gas considered to be non-conservative, which depends on the hour of the day, the distribution in phytoplankton patches as indicated by Lara-Lara \& Alvarez Borrego ${ }^{20}$ and consequently the site concentrations of oxygen where determined. Therefore, this parameter did not seem to show changes in the 50 years considering the various natural environmental factors, outside of the population increase that augmented slightly more than $45 \%$ from 1960 to 2010 INEGI, ${ }^{21}$ which would imply longer intervals due to increases in urban discharges and agricultural runoff that would manifest even conditions with a greater tendency to hypoxia, due to the consumption of gas in the oxidation of organic materials.

In relation to nutrient contents, were a wide heterogeneity concentration, determined in the three months of sampling, with the highest levels of: total phosphorus (16.7 to $40.7 \mu \mathrm{M}$ ), ammonium $(17.3$ to $20 \mu \mathrm{M})$, and total nitrogen $(35.7$ to $428.6 \mu \mathrm{M})$ in August, in which being the lowest contained within the highest contents, where in all cases above that recorded for coastal lagoons. In particular, ammonium predominated over nitrates and nitrites, which may indicate a generalized influence of urban discharges and leachate from fisheries and be distributed throughout the lagoon by the dynamics of circulation and the effect of the wind, which even moves sediments 
that have accumulated excess nutrients, as determined by Arenas \& de la Lanza Espino ${ }^{22}$ in the lagoon of Huizache and Caimanero. The removal of nutrients contained in the sediment by tide, increase or decrease the phosphorus concentration; for example, Aguiñaga \& Alvarez-Borrego ${ }^{23}$ in Estero Punta Banda (Baja California) determined that phosphorus concentrations were higher during the low tide $\left(\mathrm{PO}_{4} \max =30 \mu \mathrm{M} ;\right)$ with respect to these at high tide $\left(\mathrm{PO}_{4} \max =3\right.$ $\mu \mathrm{M})$. This suggests that during the high tide there is a water inflow to the sediments and during the low tide phosphates emerge from the interstitial water of the sediments. The same phenomenon occurs with the ammonium in low tide $\left(\mathrm{NH}_{4} \max =50 \mu \mathrm{M}\right)$ with respect to the same at high tide $\left(\mathrm{NH}_{4} \max =5 \mu \mathrm{M}\right)$; condition applicable to the Alvarado lagoon. In a study between 1986-87, de la Lanza Espino \& Lozano Montes ${ }^{11}$ determined a wide local and monthly variation in nutrient content, emphasizing that nitrites (intermediate form of inorganic nitrogen) only at the mouth of the Papaloapan river and in September had punctually concentration up to $7 \mu \mathrm{M}$ and the nitrates to $165 \mu \mathrm{M}$, that could be result of the additions of fertilizers in the agricultural areas of that river. Although for March and May the contents oscillated between the undetectable up to $5 \mu \mathrm{M}$ of $\mathrm{NO}_{2}$ and $43 \mu \mathrm{M}$ of $\mathrm{NO}_{3}$ in the case of ammonium fluctuated of 15 to $25 \mu \mathrm{M}$ which are also considered high. Morán-Silva et al..$^{14}$ recorded between in 2000-01 high ammonium contents between $42.43 \mu \mathrm{M}$ and $2.0 \mu \mathrm{M}$ depending on the epoch and the sampling location; the variation of nitrite was also from $3.54 \mu \mathrm{M}$ to undetectable; in the case of nitrates from 0.67 to $7.9-10.6 \mu \mathrm{M}$; the total phosphorus varied from $3.5 \mu \mathrm{M}$ to $18.8 \mu \mathrm{M}$ and orthophosphates of $0.37-0.48$ to $4.5-6.2 \mu \mathrm{M}$.

According to Herrera-Silveira et al. ${ }^{16}$ in 1990, the Alvarado lagoon system showed serious threats, including: 1) reduction and fragmentation of the habitat of flora and fauna due to the expansion of the agricultural frontier; 2) reduction and deterioration of the mangrove caused by extractive activities, extensive cattle ranching and other changes in land use, (3) reduction of species of economic importance for local fisheries caused by increased fishing effort, use of prohibited fishing effort and changes in water quality due to different types of pollution, and 4) problems associated with the siltation of water bodies caused by erosion in the upper parts of the river basin by the elimination of forest cover, among others. These authors considered this lagoon system in a degree of eutrophication based on maximum $\mathrm{PO}_{4}$ content of $19 \mu \mathrm{M}$ and an chlorophyll "a" of $219 \mathrm{mg}$ / L, Contreras Espinosa \& Warner ${ }^{13}$ in a bibliographic compilation without defining the year of sampling, the spatial and temporal variation, refer contents of 5 to $29 \mu \mathrm{M}$ of ammonium, of 0.5 to $21 \mu \mathrm{M}$ of $\mathrm{NO}_{2}+\mathrm{NO}_{3}$ and of $\mathrm{PO}_{4}$ of 0.0 to $13 \mu \mathrm{M}$, but with a maximum of 19 $\mu \mathrm{M}$. which corroborated eutrophication. This indicates that the trophic state in the Alvarado lagoon has been presented for 30 years, based on the records of de la Lanza Espino \& Lozano Montes ${ }^{11}$ determined in 1986-87 until registered in 2015-2016

Increased urban and agricultural settlements have surpassed normal levels of these nutrients compared to other coastal systems, especially in total phosphorus and total nitrogen concentrations including organic forms. Based on the LOICZ model, it was estimated for 2016 the export of the Alvarado lagoon to the adjacent sea of 77.65 $\mathrm{mmol} \mathrm{m} \mathrm{m}^{-2}$ day for total phosphorus and $479.72 \mathrm{mmol} \mathrm{m}^{-2}$ day for the total nitrogen in the rainy season. Although this model estimates a residence time of 0.8 days as a result of which it was calculated for marine intercommunication, however, it was also determined from two to three days taking into account the two lagoons with a geomorphological isolation (Camaronera and Tlalixcoyan), times that would lead to purifying the lagoon, but the incessant anthropogenic growth has led to an obvious eutrophication.
Between 2015-16 chlorophyll "a" also showed a wide temporal and space variations; with the lowest and homogeneous concentrations in May, but contrasting in March and August with high levels up to 22 and $48.8 \mathrm{mg} / \mathrm{m}_{3}$ respectively, which qualify the Alvarado lagoon as a eutrophic condition. These high contents of chlorophyll "a" in addition to having a temporal variation (from day to period) also have a marked spatial variation, resulting from the complex lagoon morphology. This is demonstrated by the study done by Villalobos et al. ${ }^{8}$ where in 1966 they recorded wide intervals ranging from undetectable in the marine mouth to $10.7 \mathrm{mg} / \mathrm{m}_{3}$ in Buen País lagoon in July, but in August (full rainy season) they registered up to $70.7 \mathrm{mg} / \mathrm{m}_{3}$ in Buen País (zone called resting) that is located between the lagoon Camaronera and the lagoon Arbolillo, this sampling site is characterized by its isolation it should be noted that in the year in which the said authors carried out the sampling, both agricultural and urban development on the margins of the lagoon were smaller, so that it can be considered as a normal condition or a natural eutrophication. However, it must be considered that phytoplankton (here equated as chlorophyll a content) is distributed in patches or stains as pointed out by Lara-Lara \& Alvarez Borrego ${ }^{19}$ in the Bay of San Quentin, Baja California. In this sense the distribution of pigments (chlorophyll "a") should be a first approximation of reality. In the case of chlorophyll "a" in the Alvarado lagoon, Morán-Silva et al. ${ }^{14}$ between the years 2000-2001 recorded from $4.3-18.8 \mathrm{mg} / \mathrm{m}_{3}$ to $11.5-92.6 \mathrm{mg} / \mathrm{m}_{3}$, wide variation resulting from both the time and the point local sampling. Contreras Espinosa and Warner (2004) recorded a range of 4.9 to $219 \mathrm{mg} / \mathrm{m}_{3}$, these authors in Chantuto-Panzacola in 1991 in an apparent condition of low impact by anthropogenic activities, referred from $<1 \mathrm{mg} / \mathrm{m}_{3}$ to with a maximum of $143 \mathrm{mg} / \mathrm{m}_{3}$, being an example of an extreme case of cultural eutrophication, but 25 years later (2015) determined contents of $43 \mathrm{mg} / \mathrm{m}_{3}$ decrease that may be the result of phytoplankton patches as mentioned by previous authors. Which corroborates that both "a" chlorophyll and phytoplankton determinations are approximations to reality that can be partially solved by an adequate network of sampling stations and their monitoring.

In order to estimate the bacterial contamination in the local water from the urban discharges and to integrate it to the nutrient content, it was determined that in all the samples the total coliforms were recorded in greater number, although under the water quality standards in our Country do not consider them given that they normally exist in the environment; on the other hand, the fecal bacterial ones are of human or even animal origin. According to NOM ECOL $001,{ }^{3}$ which corresponds to public services for direct or occasional contact, and focuses on the residual discharges discharged to receiving bodies, it indicates no more than $1000 \mathrm{NMP} / 100 \mathrm{~mL}$ fecal coliforms (Published in the Official Gazette of the Federation Dated September 21, 1998 by the Federal Office of Environmental Protection. ${ }^{24}$ In the case of the Alvarado lagoon, the specified number was not exceeded and could not be associated with high nutrient content because bacterial survival is short due to salinity.

\section{Conclusion}

As expected, the Alvarado lagoon presents conditions of eutrophy in different spatial and temporal degrees, associated to the discharges of the villages, the wastewater and even the agricultural runoff adjacent to the multiple basins. In the 1960s the condition was natural eutrophic (with respect to chlorophyll a concentration) but only in certain localities with restricted dynamics; 50 years later chlorophyll "a" has been maintained in an interval that shows a high trophic level. Specifically, total phosphorus and nitrogen and ammonium contents in the water, exceeded three times to register in 
35 years ago, approximately (1980 to 2015)changing to the natural to cultural eutrophication compared with other lagoon system without contamination.

Taking into account the great discharge of the Papaloapan river that closely merges with the marine mouth, was calculated with the technique of LOICZ a time of 0.8 days although with a low amplitude tide of 0.5 to 0.7 meters. The above would allow to reduce the high contents of nutrients in a satisfactory time period, as soon as the discharges will cease; however, the continuous anthropogenic contribution will maintain high levels not only of nutrients but also for any other pollutants, which have been exported to the marine area continuously through the great fluvial discharge. Likewise, the use of organophosphorus pesticides used in agriculture usually reaches the sediment, a substratum in which they can be hydrolyzed and transferred to water in different time periods (from de la Lanza Espino and Ponce in preparation), which will represent a potential source of both organic and inorganic forms that have been stored in this substrate as agriculture has been increasing.

\section{Acknowledgments}

None.

\section{Conflicts of interest}

None.

\section{References}

1. De la Lanza Espino G. Recursos Hidrológicos de México (1-104). En: Abarca F y M. Herzig (Eds.), Manual para el Manejo y Conservación de los Humedales de México. PRONATURA, SEMATNAT, NAWCC, DUMAC, RAMSAR, ENVIRONMETAL, Canadá. 2004.

2. Contreras Espinosa F, Castañeda LO, García NA. La clorofila $a$, como base para un índice trófico de las lagunas costeras mexicanas. An InstCienc Mar Limnol UNAM. 1994;21(1-2):55-66.

3. DOF, Norma Oficial Mexicana NOM-001-ECOL. Que establece los límites máximos permisibles de contaminantes en las descargas de aguas residuales en aguas y bienes nacionales. 1996.

4. Flores-Coto C, Méndez Vargas ML. Contribución al conocimiento del ictioplancton de la Laguna de Alvarado, Veracruz. An Inst Cienc MarLimnol. 1982;9(1):141-160.

5. CONABIO. Ficha técnica para la evaluación de sitios prioritarios. 2008

6. Strickland JDH, Parsons TR. A Practical Handbook of Seawater Analysis. Fisheries Research Board of Canada. 1972.

7. APHA-AWWA-WPCF. Standard Methods for Examination of Water and Wastewater. 2005.

8. Villalobos F, Gómez S, Arenas V, et al. Estudios hidrobiológicos de la laguna de Alvarado (febrero-agosto, 1966). An Inst Biol Univ Nal Autón México 46 Ser Zoología. 1975;(1):1-34.
9. Contreras Espinosa F. Comparación hidrológica de tres lagunas costeras del estado de Veracruz, México. UnivCienc. 1985;3:47-56.

10. Contreras Espinosa EF, Castañeda LO, Torres AR, et al. Nutrientes en 39 Lagunas Costeras Mexicanas. Rev Biol Trop. 1996;44(2):417-425.

11. De la Lanza Espino G, Lozano Montes H. Comparación fisicoquímica de las lagunas de Alvarado y Términos. Hidrobiol. 1999;9(1):15-30.

12. Arriaga Cabrera L, Aguilar V, Espinoza JM. Regiones prioritarias y planeación para la conservación de la biodiversidad(433-457). En:CONABIO(Ed.), Capital natural de México, vol II: Estado de conservación y tendencias de cambio. 2001.

13. Contreras Espinosa F, Warner BG. Ecosystem characteristics and management consideration for coastal wetlands I Mexico.Hydrobiol. 2004;511:233-245.

14. Morán-Silva A, Martínez Franco LA, Chávez-López R, et al. Seasonal and spatial patterns in salinity, nutrients, and chlorophyll $a$ in the Alvarado lagoon system, Veracruz, Mexico. G Caribb Res. 2005;17:133-143.

15. Calva Benítez LG, Torres Alvarado MR. Textura de sedimentos y carbono orgánico en el sistema costero lagunar Alvarado, Veracruz. Contactos. 2011;81:11-16.

16. Herrera-Silveira JA, Morales-Ojeda SM, Cortes-Balan TO. Eutrofización en los ecosistemas costeros del Golfo de México: V.1. SEMARNAT-NOAA-GEF-UNIDO. 2011.

17. Ruiz-Fernández AC, Maanan M, Sánchez-Cabeza AJ, et al. Cronología de la sedimentación reciente y caracterización geoquímica de los sedimentos de la Laguna de Alvarado, Veracruz (suroeste del Golfo de México. Cienc Mar. 2014;40(4):291-303.

18. Ledesma G. Unidades y conversiones del oxígeno disueltoEvaluación hidroacústica de la distribución y biomasa de recursos pelágicos frente a la costa peruana. Instituto del Mar del PerúInforme, ISSN 0378 - 7702. 2009;36(1-2):86-86.

19. CHEE BA. Aspectos hidrológicos en la laguna de Alvarado, Veracruz. Tesis professional, UABC. 1981.

20. Lara Lara, JR, Álvarez Borrego S. Ciclo anual de clorofilas y producción orgánica primaria en Bahía San Quintín, B.C.,Cienc Mar. 1975;2(1):7797.

21. http://www.inegi.org.mx/geo/contenidos/geoestadítica/ consultalocalidades.a.spx

22. Arenas V, de la Lanza-Espino G. Metabolismo como determinante de nutrientes en sedimentos ricos en materia orgánica en una laguna costera. Cienc Mar UABC. 1990;16(3):45-62.

23. Aguiñiga GS, Álvarez-Borrego S. Intertidal sediments pore water nutrients in a coastal lagoon of northwestern Baja California. Res Joint, Oceanography Assembly. 1988.

24. De la Lanza Espino G, Hernández Pulido S. Nutrientes y productividad primaria en sistemas acuícolas (27-61). En: Martínez Córdova LR (Eds.), Ecología de los Sistema Acuícolas. AGT Editor, SA México. 1998. 